\title{
Cropping Practices and Effects on Soil Nutrient Adequacy Levels and Cassava Yield of Smallholder Farmers in Northern Zambia
}

\author{
Peter Kaluba $\mathbb{D D}^{1,2}$ Sydney Mwamba, ${ }^{2,3,4}$ Dany Pascal Moualeu-Ngangue, ${ }^{2}$ Martin Chiona, ${ }^{5}$ \\ Kalaluka Munyinda, ${ }^{4}$ Etti Winter, ${ }^{6}$ Hartmut Stützel, ${ }^{2}$ and Benson H. Chishala ${ }^{1}$ \\ ${ }^{1}$ Department of Soil Sciences, School of Agricultural Sciences, P. O Box 32379, University of Zambia, Lusaka, Zambia \\ ${ }^{2}$ Institute of Vegetable Production Systems, Leibniz Universität Hannover, Herrenhäuserstr. 2, Hannover 30419, Germany \\ ${ }^{3}$ Seed Control and Certification Institute, Ministry of Agriculture, Chilanga, Zambia \\ ${ }^{4}$ Department of Plant Sciences, School of Agricultural Sciences, P. O Box 32379, University of Zambia, Lusaka, Zambia \\ ${ }^{5}$ Zambia Agriculture Research Institute, Mansa Research Station, P. O. Box 710129, Mansa, Zambia \\ ${ }^{6}$ Institute for Environmental Economics and World Trade, KönigswortherPlatz 1 30167, \\ Hannover Leibniz University of Hannover, Hannover, Germany
}

Correspondence should be addressed to Peter Kaluba; peter.kaluba@unza.zm

Received 19 April 2021; Accepted 5 August 2021; Published 19 August 2021

Academic Editor: Othmane Merah

Copyright (C) 2021 Peter Kaluba et al. This is an open access article distributed under the Creative Commons Attribution License, which permits unrestricted use, distribution, and reproduction in any medium, provided the original work is properly cited.

Cassava is a staple food and a major source of income for many smallholder farmers. However, its yields are less than $6 t$ ha ${ }^{-1}$ compared to a potential yield of $20-25 \mathrm{tha}^{-1}$ in Zambia. Understanding cropping practices and constraints in cassava production systems is imperative for sustainable intensification. Therefore, a survey of 40 households each with three fields of cassava at 12,24, and 36 months after planting (MAP) was conducted. Analyzed soil data, leaf area index (LAI), intercepted photosynthetically active radiation, and management practices from 120 fields were collected and subjected to descriptive statistics. To explain yield differences within the same cassava growth stage group, the data were grouped into low- and high-yield categories using the median, before applying a nonparametric test for one independent sample. Stepwise regressions were performed on each growth stage and the whole dataset to determine factors affecting tuber yield. Cassava intercropping and monocropping systems were the main cropping systems for the 12 and 24-36 MAP, respectively. Cassava yields declined by 209 and $633 \mathrm{~kg} \mathrm{ha}^{-1}$ at 12 and $36 \mathrm{MAP}$ due to soil nutrient depletion for each year of cultivation until field abandonment at 8-9 years. Fresh cassava yields ranged from 3.51-8.51, 13.52-25.84, and $16.92-30.98 t \mathrm{ha}^{-1}$ at 12,24 , and $36 \mathrm{MAP}$, respectively. For every one unit increment in exchangeable $\mathrm{K}\left(\mathrm{cmol}(+) / \mathrm{kg}\right.$ soil), cassava yield increased by 435,268 , and $406 \mathrm{~kg} \mathrm{ha}^{-1}$ at 12 , 24, and 36 MAP, respectively. One unit increment of magnesium ( $\mathrm{cmol}(+) / \mathrm{kg}$ soil) gave the highest yield increase of $525 \mathrm{~kg} \mathrm{ha}^{-1}$ at 24 MAP. The low levels of soil organic carbon explained the deficient nitrogen in cassava fields, which limits the LAI growth and consequently reduced intercepted radiation and low yields. The effect of exchangeable $\mathrm{K}$ on growth was limited by the moderate availability of $\mathrm{Mg}$ and low $\mathrm{N}$, thus the need for balanced fertilizer regimes.

\section{Introduction}

Cassava (Manihot esculenta Crantz) is the second most important source of calories and contributes about $30 \%$ of daily calorie requirements per person in Africa [1]. SubSaharan Africa (SSA) is the largest producer of cassava in the world [1]. Apart from the tubers, cassava leaves are harvested and consumed as an important source of protein and micronutrients by both humans and livestock [2]. Until recently, cassava was mainly grown as a subsistence crop by smallholder farmers. Cassava is able to thrive and produce reasonable yields where many crops fail completely [3] because of its tolerances to drought conditions. With improved management, cassava could be the ultimate crop to combat food insecurity and provide a source of income even in remote parts of SSA. Furthermore, there is an increasing demand for cassava as a raw material by local agro and industrial markets for many products $[1,4]$. Moreover, the 
rapid increase in population also exacerbates the demand for food and fuel, exerting more pressure on land availability for agriculture, especially in Africa [5, 6]. These new patterns of demand present an opportunity along the value chain of cassava in Zambia. Low yields characterize current smallholder cassava production systems in Zambia.

Cassava is the main crop grown by smallholder farmers in shifting cultivation systems in Northern Zambia. Recent adverse effects of climate variability and change [7] have increased dependence on cassava production since it thrives and produces reasonable yield where other crops fail completely. However, with less than $6 t \mathrm{ha}^{-1}$, the productivity of the crop is below the potential of $20-25 t \mathrm{ha}^{-1}$ [8] under similar farming systems in Zambia. There are many causes of low cassava yields in smallholder farmer's fields. These include poor farming practices [9-11], poor weed management [11], and little or no use of inorganic fertilizer and pesticides. Moreover, farmers perceive cassava to be tolerant to poor soils [12-14] and, therefore, it is grown on soils low in nutrients. Fresh cassava tuber has been reported to contain about $4 \mathrm{~kg} \mathrm{~K}$ per ton [3]; thus, a yield of 30-40 $t$ $\mathrm{ha}^{-1}$ can remove about $120-160 \mathrm{~kg} \mathrm{~K}^{-1}$ [12]. Similarly, Howeler [15] has reported a tuberous yield of $30 \mathrm{t} / \mathrm{ha}$ to remove major nutrient amounts of $164 \mathrm{~kg} \mathrm{~N} \mathrm{ha}^{-1}, 31 \mathrm{~kg} \mathrm{P}$ $\mathrm{ha}^{-1}$, and $200 \mathrm{~kg} \mathrm{~K} \mathrm{ha}^{-1}$ at harvest from the soil. Therefore, after a few of years of cropping, the land is exhausted and a new land is opened up by lopping of trees $[6,12,14,16,17]$.

Understanding the productivity constraints of cassava production systems is an important prerequisite to increase cassava productivity to satisfy the demand of the escalating population. Productivity is determined by radiation interception, radiation use efficiency, and harvest index [18]. Radiation interception depends on the green leaf area duration and the ability of the leaf area to intercept light, characterized by the light extinction coefficient $(k)$. Differences in canopy architecture may result in a variation of light interception and may also affect the conversion of intercepted radiation into dry matter [18]. Tesfaye et al. [19] and Sennhenn et al. [20] found values for $k$ of less than 0.5 in legumes as an adjustment to water deficit. Begg [21] noted such adaptive mechanisms to be important in grain legumes to cope with drought stress. A good understanding of the constraints of cassava production systems is imperative to intensify cassava production in a sustainable way to meet the current and future large demand for cassava. Therefore, the objective of this study was to investigate the constraints to cassava tuber yield in smallholder farming systems in Northern Zambia. The specific objectives were (i) to evaluate cropping management practices in cassava systems, (ii) to assess the effects of management practices on selected soil nutrient adequacy levels and tuber yield, and (iii) to assess the factors affecting cassava tuber yield.

\section{Materials and Methods}

2.1. Description of the Study Area. The study was conducted in the Mantampala Camp of Nchelenge District in Luapula Province, Northern Zambia $\left(9^{\circ} 19.028^{\prime} 59^{\prime \prime} \mathrm{S}, 28^{\circ} 50^{\prime} 44^{\prime} \mathrm{E}\right.$, and at an elevation of $959 \mathrm{~m}$ above sea level). The area lies in agroecological region III, which is characterized by an average annual rainfall of above $1,071.6 \mathrm{~mm}$ and an average annual temperature of $22.1^{\circ} \mathrm{C}$ (Figure 1) and experiences a tropical savanna climate with three seasons, namely, winter (May-August), dry (September-October), and rainy season (November-April). The main soil types in the region include Ferric and Orthic Acrisols formed from underlying acid igneous or siliceous sedimentary rocks [22]. Agriculture is the main livelihood activity in Mantampala with cassava being the staple crop and source of income. Other crops interplanted with cassava include maize, groundnuts, common beans, cowpea, and millet. Cassava is grown under shifting cultivation (chitemene system) which involves slashing grass and burning of lopped tree branches as a source of nutrients and fuel. After two to three cycles of cropping, the land is exhausted and cannot provide sufficient nutrients to meet crop demand. Thereafter, the land is left to regenerate via fallowing $[12,16]$. Fallowing is a prerequisite for maintaining long-term plant-available nutrient pools and crop yields in many tropical cultivation systems [14]. The shifting cultivation system is only sustainable where there is a low population density and abundant land [5, 22].

2.2. Sampling Design. Ten well-spaced villages were selected for this study, giving a variable number of inhabitants and ease of access to and from the district. In each village, 3 to 7 farmers were selected each with three fields of cassava at 12, 24, and 36 months after planting (MAP). These farmers were chosen so that their fields would cover the largest possible variation in soil characteristics. For each farmer, information for the three fields was obtained using semistructured interviews. In total, the dataset comprised 40 farmers and 120 fields. The fieldwork was conducted between October and December 2017 and a follow-up in 2018 to fill up the necessary information which was not covered during the first survey.

\subsection{Data Collection}

2.3.1. Management and Biophysical Data. In the farmer fields, semistructured interviews were conducted in situ with the farmer owning the field or other members of the household. Interviews were focused on the previous use of the fields and their current management. In each farmer's field, the coordinates were obtained using GPS to calculate the field sizes in Arc GIS 10.

To assess the cassava cropping practices, basic information on age of the field and cassava, land clearing, preparation, planting times, weeding frequency and cassava varieties planted and legumes intercropped with cassava, and period of cropping before fallow was recorded. Other information obtained included input use (fertilizer, pesticides, and fungicides) and leaf harvesting frequency.

2.3.2. Soil Samples. In each farmer's field, the topsoil $(0-30 \mathrm{~cm})$ samples were collected at five random points using an auger, and the subsamples were thoroughly mixed 


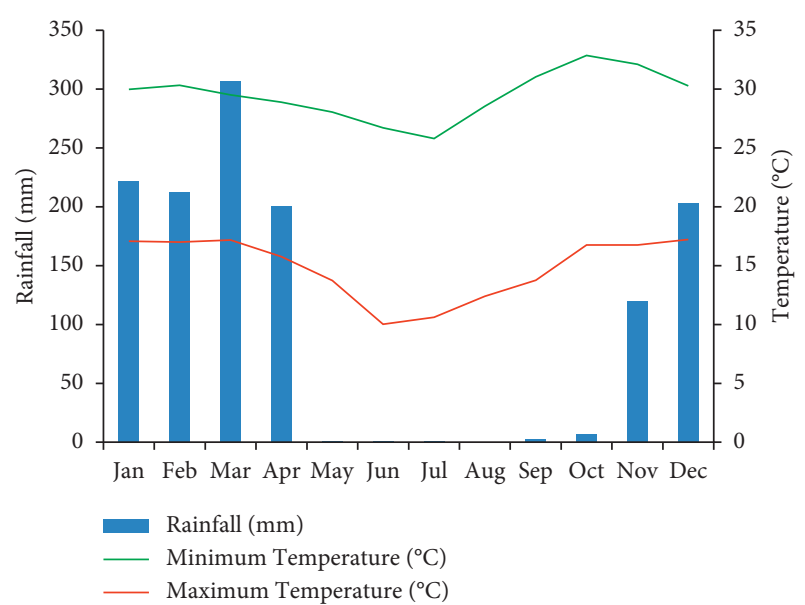

FIGURE 1: Mean monthly maximum and minimum temperatures with total monthly rainfall during the 2017 survey period. Bar graphs show the total monthly rainfall, and the line graphs show the mean, maximum, and minimum temperature.

to make one composite sample per field. In total, 120 composite samples were collected. The soils were dried and sieved through a $2 \mathrm{~mm}$ sieve before being analyzed for selected soil chemical and physical properties. Soil reaction $(\mathrm{pH})$, soil texture, exchangeable acidity, soil carbon, total nitrogen, exchangeable cations, and phosphorus were determined. The analyses were carried out in triplicate. The particle size distribution was assessed following the Bouyoucos method, soil organic carbon content was determined following the Walkley-Black procedure [23], soil $\mathrm{pH}$ was measured in $1: 2.5$ soil water suspension using a $\mathrm{pH}$ meter, total nitrogen content was analyzed by the Kjeldahl method with sulphuric acid and selenium as a catalyst [24], available phosphorus was extracted using the Bray 1 method and colorimetrically measured using the molybdenum blue method, and exchangeable bases were extracted using ammonium acetate $\left(\mathrm{NH}_{4} \mathrm{OAc}\right)$ buffered at $\mathrm{pH}$ 7. Magnesium and potassium were determined after strontium chloride addition using an atomic absorption spectrophotometer (AAS) (Analyst 400., PerkinElmer Life and Analytical Sciences, Shelton, USA), while the other cations ( $\mathrm{Na}$ and $\mathrm{Ca}$ ) were determined using a flame photometer [25].

\subsubsection{Leaf Area Index, Light Interception, and Tuber Yield.} Leaf area index (LAI) was measured in established cassava fields at three locations using the LAI2200 (LICOR Inc., Lincoln, NE, USA). Similarly, the intercepted photosynthetically active radiation (PAR) was measured at each of the three locations in the field using the line quantum sensor and LI COR 190R (LICOR Inc., Lincoln, NE, USA). The relationship between intercepted light and LAI was calculated using equation (1) as carried out by Veltkamp [26]:

$$
\operatorname{Ln}\left(\frac{I}{I_{0}}\right)=-K \mathrm{LAI}
$$

where $I=$ light received beneath the canopy (three positions per plot), $I_{0}=$ incoming light just above the crop canopy (one measurement per plot), and $k=$ light extinction coefficient.
The $k$ values for cassava at maturity stages of 12,24 , and 36 MAPS at the time of the survey were calculated as the slope of a regression line of ln (light transmission) as a function of LAI, according to Veltkamp [26].

Since the planting patterns were not orderly in some fields, harvesting of cassava was carried out based on the number of plants after the LAI and light interception were measured. The plant population in each field was obtained by counting the cassava stands in a $3 \mathrm{~m}$ by $3 \mathrm{~m}$ area. Thereafter, the tubers were dug and counted before weighing for each of the 120 fields. Total fresh yield weight of each field and the number of plants in a $3 \mathrm{~m}$ by $3 \mathrm{~m}$ area were used to calculate fresh cassava yield $\left(t \mathrm{ha}^{-1}\right)$. To convert to dry matter tubers per ha, a factor of 0.34 was used, similar to the work of Alves [27].

\subsection{Statistical Data Analysis. Descriptive statistics were} applied to analyze cropping management practices in cassava fields at 12, 24, and 36 months after planting. Nutrient levels in crop fields were evaluated for soil nutrient adequacy for cassava production by comparing soil values to known critical nutrient levels and sufficiency ranges recommended for optimal cassava growth for each soil type $[28,29]$. An analysis of variance (ANOVA) was conducted on the data to compare the effects of cassava management practices on soil properties for each cassava maturity group and on the whole dataset. Effects of management practice and soil properties on cassava yield within each maturity group were obtained by separating each group into high and low yields using the median. These were analyzed using nonparametric tests for one independent sample using the Kruskal-Wallis test or linear model. Statistical analyses were conducted in R-3.5.2 (R Core Team, 2016).

Cassava tuber yield-determining factors were identified and estimated using stepwise regression models according to the maturity group at 12,24 , and 36 MAPS. The variables that considered yield-determining factors were social, management, cassava, and soil properties. Correlation analysis was performed on the variables, and explanatory variables that had a significant relationship with cassava tuber yield were selected for stepwise regression analysis $(P<0.05)$. All variables were further scaled to ensure standardization of the different variables in the model. Explanatory variables that had a significant correlation $(r)$ with yield and/or exhibited a pattern of covariation with cassava tuber yields were selected for further analysis. The significance of the different factors on the yield were evaluated at $P$ value $<0.05$ significance level.

\section{Results and Discussion}

3.1. Crop Management Practices in Cassava Systems. The cropping and management practices in cassava farming are presented in Table 1. Cassava is normally planted during October to November depending on the onset of the rains. The main cropping system is cassava intercropping in the first year of cassava planting. The main crops in cassava intercropping are cereals and legumes. Improved varieties of 
TABLE 1: Cropping practices for cassava in the study area.

\begin{tabular}{lcc}
\hline Characteristics & Key attribute & Proportion of respondents $(\%)(n=40)$ \\
\hline \multirow{2}{*}{ Cropping practice } & Intercropping & 100 \\
& Monocropping & 0 \\
Most intercropped crop & Maize & 45.8 \\
& Beans & 25.3 \\
Variety & Cowpea & 8.3 \\
& Improved varieties & 95 \\
Input use & Local varieties & 5 \\
& Fertilizer & 0 \\
& Slash and burn & 100 \\
Land use duration (years) by gender & Pesticide and fungicide use & 0 \\
& Female (11) & 9.2 \\
\end{tabular}

cassava were most commonly grown compared to the local varieties at $95 \%$ and 5\%, respectively. Farmers practice the slash and burn system which supplies wood ash which ameliorates soil acidity and supplies nutrients for cassava production. Therefore, no inorganic fertilizers and pesticides were used in cassava production.

Consistent with this study, several researchers have observed cassava intercropping as the most dominant practice in Africa [30-32]. Farmers stated that reducing risk of crop failure and weed suppression is the main reason of practicing intercropping $[30,33,34]$. Furthermore, the farmers indicated that cassava intercropping saves labour from preparing separate lands for other crops. The other crops benefited from the slash and burn practice under intercropping. In the study area, cassava intercropping was not practiced at 24 and $36 \mathrm{MAP}$ to avoid the competition for light and nutrients. The plant density of more than 20,000 plants/ha was very high for intercropping (Table 2). The farmers also stated that cassava is intercropped with maize, beans, and cowpea arranged in order of importance (Table 1). The beans and cowpea provide a cheap source of protein while fixing nitrogen. These findings are consistent with many studies that have shown cassava intercropping with maize and legumes as the dominant crops [30, 31]. Similar to this study, Munyahali [30] also reported common bean and maize as the main crops in cassava intercropping in DR Congo. Similarly, Fermont et al. [33] found maize as the most intercropped crop with cassava in Kenya and Uganda.

Cassava yield variation against the number of years of field cultivation is presented in Figure 2. For every year of cultivation without fertilizer application, the cassava yield decreased by 633 and $209 \mathrm{~kg} \mathrm{ha}^{-1}$ at 36 and 12 MAP, respectively.

The households depend on agriculture as a source of food and income. Cassava is the staple food in the study area, and all households have cassava at different maturity stages of 12, 24, and 36 MAP (Table 1). The field with cassava at 36 MAP is the main source of tubers, although sometimes cassava at $24 \mathrm{MAP}$ is harvested. In an event of food scarcity at the household level, the earliest time the farmers could harvest the tubers is at 12 MAP old for the improved varieties. The majority of farmers use improved varieties in preference to local varieties (Table 1). Munyahali [30] also reported improved cassava varieties to be the most cultivated in Uvira, DR Congo, to mainly control cassava mosaic disease.

Generally, farmers do not apply any inorganic fertilizer to cassava fields (Table 1). Some nutrients to support cassava growth are provided by the ash from the slash and burn practices in shifting cultivation (Table 1). According to Biratu et al. [35], the high costs of fertilizers (Table 1), nonavailability at the right time, and poor crop response in dry periods exacerbated by technical and institutional issues constrain the use of inorganic fertilizer. Several authors have also reported that farmers perceive cassava to be tolerant to low soil fertility status [13, 28, 36, 37]. Similarly, Leihner [36] reported that farmers believed that cassava could restore the fertility of degraded soils and so does not require fertilization. This practice of not applying fertilizer to the cassava systems is the reason many farmers grow cassava on marginal land or land that is about to be abandoned with natural regeneration [38]. Studies have shown that local varieties tend to be more tolerant to low soil fertility compared to improved varieties when grown without fertilizer [39]. Ezui et al. [9] explained the nonuse of fertilizer as one of the reasons of the substantial yield gap between actual productivity of farmers' fields and the potential cassava productivity. The fact that farmers practice slash and burn as an alternative source to inorganic fertilizer is an indication of the need for fertilizer application. The yield loss of $622 \mathrm{~kg} \mathrm{ha}^{-1}$ at $36 \mathrm{MAP}$ is higher than $209 \mathrm{~kg} \mathrm{ha}^{-1}$ at 12 MAP because of the many number of years of cassava cultivation without applying fertilizer (Figure 2). The yield loss at $24 \mathrm{MAP}$ was negligible since the fields and yields were not variable. This is supported by the overall average land cropping period before abandonment of the field, which is 8.6 years based on the results from semistructured interviews (Table 1). The farmers resort to opening up of the new fields to meet the escalating cassava demand $[14,16,37,40]$. This land use duration contradicts earlier findings by Mansfield et al. [22] who reported 4-6 years in the northern part of Zambia. The observed increase in the landuse duration in this study could be attributed to increased population and may result in high rates of deforestation and degradation of the environment [17]. 
TABle 2: Comparison of cassava characteristics in farmers' field and light extinction coefficient at 12, 24, and 36 MAPS ( \pm standard deviation).

\begin{tabular}{lccc}
\hline & & Cassava age \\
Property & 12 & Months after planting & 36 \\
& & $21760 \pm 11168$ & $26294 \pm 20073$ \\
Plant density (/ha) & $23794 \pm 14764$ & $1.52 \pm 0.55$ & $2.07 \pm 0.61$ \\
LAI & $1.31 \pm 0.44$ & $55.95 \pm 10.01$ & $70.43 \pm 12.14$ \\
Intercepted radiation (\%) & $49.07 \pm 14.66$ & $0.58 \pm 0.25$ & $0.64 \pm 0.13$ \\
Light extinction coefficient & $0.56 \pm 0.17$ & $19.68 \pm 6.16$ & $23.95 \pm 7.03$ \\
Fresh root tuber yield $\left(t\right.$ ha $\left.^{-1}\right)$ & $6.01 \pm 2.50$ & & \\
\hline
\end{tabular}

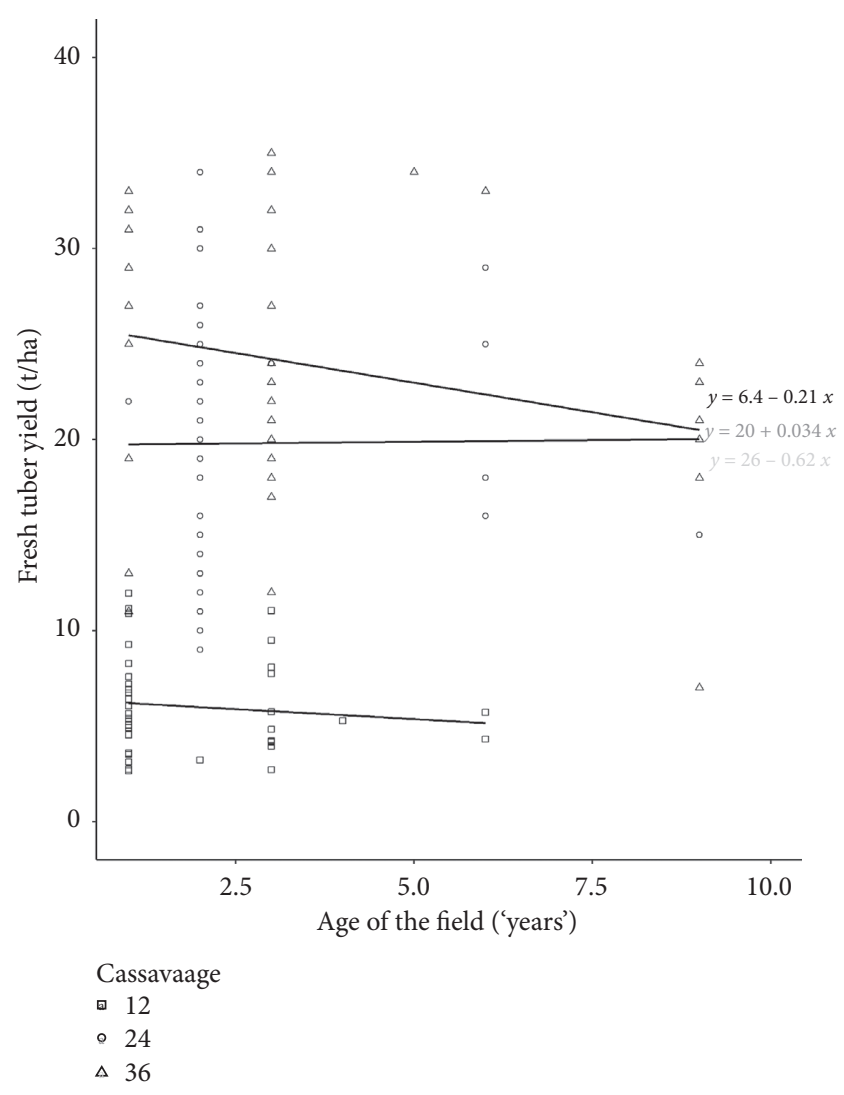

FIGURE 2: Variation in cassava yield with the duration of field cultivation.

The management practices, namely, weeding frequency, leaf harvesting frequency, and field characteristics, namely, field texture class and sizes, are presented in Table 3. The respondents indicated that weeding was commonly carried out using a hand hoe (Table 1) and, therefore, herbicides were never used in controlling weeds. On average, more than $70 \%$ of farmers weeded in cassava in the first and second year and no weeding was carried out in cassava in the third year. Generally, from planting to harvest, most farmers weeded twice, with the most frequent weeding carried out in the first-year fields compared to the second-year fields. This is due to higher weed pressure in cassava fields in the first year than cassava in the second year which has developed a canopy which reduces weed pressure. The farmers harvest and cook cassava leaves as vegetable of cassava at maturity stages of 12 and 24 MAP.
Farmers mainly control weeds using the hand hoe (Table 1), which is mostly carried out twice from cassava planting to harvesting (Table 3). This is inconsistent with the three weed operations per cassava growing cycle recommended by the IITA [41] and NACWC [42]. Contrary to our findings, Munyahali [30] reported at least three weeding operations per cassava growing cycle are practiced by the majority of farmers in all sites in DR Congo. In this study, weeding was mostly carried out by family members who took longer to finish and this affects the growth of cassava. These findings are consistent with those reported by Enete et al. [43], who found that family labour is often sufficiently available and this leads to weeds adversely affecting crop yields. According to Leihner [36], the critical period for weed competition in cassava lasts up to 4 months after planting (MAP). 
TABLE 3: Management practices for cassava and field characteristics in the study area $( \pm s . d=$ standard deviation).

\begin{tabular}{|c|c|c|c|c|}
\hline \multirow[b]{2}{*}{ Practice } & \multirow[b]{2}{*}{ Attribute } & \multicolumn{3}{|c|}{ Cassava age (months) } \\
\hline & & 12 & $\begin{array}{l}24 \\
\%\end{array}$ & 36 \\
\hline \multirow{3}{*}{ Weeding frequency (per year) } & 1 & 72.5 & 72.5 & 0 \\
\hline & 2 & 27.5 & 25 & 0 \\
\hline & 3 & 0 & 2.5 & 0 \\
\hline \multirow{5}{*}{ Monthly leaf harvesting frequency } & 1 & 15 & 20 & 0 \\
\hline & 2 & 40 & 42.5 & 0 \\
\hline & 3 & 12.5 & 12.5 & 0 \\
\hline & 4 & 32.5 & 25 & 0 \\
\hline & Loamy sand (\%) & 12.5 & 12.5 & 12.5 \\
\hline \multirow{2}{*}{ Texture class } & Sandy loam (\%) & 75 & 62.5 & 62.5 \\
\hline & Sandy clay loam $(\%)$ & 12.5 & 25 & 25 \\
\hline Field size & Area (ha) & $0.58 \pm 0.29$ & $0.55 \pm 0.43$ & $0.53 \pm 0.37$ \\
\hline
\end{tabular}

The tender leaves in the first year are mostly used for household consumption, while the ones obtained in the second year are mainly for selling. The leaf harvesting frequencies of 2 and 4 times monthly were the most common and were carried out based on the household demands. The time of the first leaf harvesting was generally at 6 months after planting. Leaf harvesting is more frequent during dry seasons as cassava leaves are present unlike other seasonal traditional vegetables. The leaf harvesting frequency was negatively correlated and nonsignificantly affected the yield $(r=-0.10, P>0.05)$. The leaf harvesting interval observed in this study (Table 3 ) is in agreement with that in the work of Munyahali et al. [11], who observed 2- or 4-week leaf harvesting intervals starting at 3-4 MAP for household consumption. They reported that this harvesting had insignificant effects on tuber yields. However, Lockard et al. [44] recommended a leaf harvesting interval of at least 2 months starting at 4 MAP since monthly intervals significantly reduced tuber size. The nonsignificant effect of leaf harvesting on tuber yield in the study could be attributed to the larger field size and observation at the plant level, which requires further research.

The sandy loam textured soils were dominant in the visited fields, followed by sandy clay loam and loamy sand which were the least. Field sizes were variable and less than 1 ha in the whole study area. The average cassava field size was 0.53 ha with a range of $0.19-0.92$ ha characterized with higher variability (Table 3 ). There has been a decrease in field sizes compared to those reported by Mansfield et al. [22] who found field sizes to range between 1.6 and 2.0 ha in the northern part of Zambia. This pattern of smaller cassava fields has also been reported by Junqueira et al. [45] in the Amazon Basin under shifting cultivation. The authors attributed smaller fields to a strategy to combat the higher weed pressure on fertile land when combined with fastgrowing species or landraces with shorter cycles. Similarly, Munyahali et al. [30] reported smaller field sizes with an average of 0.9 ha in Kivu, Democratic Republic of Congo (DR Congo), although they were slightly larger than those found in this study. Similar results of average field sizes of other studies are 0.3 to 0.9 ha by Fermont et al. [34] in Kenya and Uganda and 0.1-0.98 ha in Kongo Central Province and between 0.2 and 4.4 ha in Tshopo Province of DR Congo by
Kintché et al. [10]. In this study, the fields were located very far from home because of shifting cultivation.

\subsection{Effects of Cassava Cropping Practices on Selected Nutrient} Adequacy Levels. Physicochemical soil properties in farmers' field of cassava in fields of 12, 24, and 36 MAPS are presented in Table 4. The soil $\mathrm{pH}$ and total nitrogen were moderately suitable for optimal cassava production. Generally, soil parameters $(\mathrm{K}, \mathrm{Ca}$, and $\mathrm{P})$ were highly suitable for optimal cassava production while magnesium $(\mathrm{Mg})$ was moderately suitable. Meanwhile, total nitrogen, $\mathrm{Cu}$, and $\mathrm{Zn}$ were very low compared to the cassava production requirement. Soil organic carbon ranged from low suitability levels for cassava at 12 and 24 MAP to moderately suitable for matured cassava at 36 MAP. Most soil physicochemical soil properties were strongly correlated with cassava yields, except total nitrogen $(r=0.002)$.

The soil $\mathrm{pH}$ varied from very strongly acidic to strongly acidic and moderately suitable for optimal cassava production according to Howler [34] (Table 4). In this study, the soil pH was alkaline in cassava at 36 and 24 MAP maturity stages than 12 MAP. These findings are in agreement with those reported by Giardina et al. [46] who found that soils under shifting cultivation are generally less acidic than those under forest because of the combustion of vegetation and subsequent addition of ash that may increase the soil $\mathrm{pH}$.

The results show that exchangeable cations; potassium, calcium, and phosphorus were above the critical levels (Table 4) [34]. This result contradicts several findings in the literature which have reported low soil exchangeable potassium which limits cassava tuber yield $[3,47,48]$. Generally, there were higher amounts of soil exchangeable potassium at 12 MAP than cassava at 24 and 36 MAP. This trend of higher exchangeable $\mathrm{K}$ could be explained by the immediate effects of the slash and burn practice in recently opened fields with cassava at 12 MAP. Meanwhile, the low values of exchangeable $\mathrm{K}$ at 24 and 36 MAP could be attributed to the high uptake of exchangeable $\mathrm{K}$ during the growing period. These findings are in agreement with those by many other authors who have reported cassava to take up more exchangeable potassium than any other nutrient during the growing season [3, 47-50]. Similarly, Pellet and 
TABLE 4: Chemical and physical analyses of soil samples collected in cassava fields of varying maturity at 12, 24, and 36 MAPS and their suitability for cassava production.

\begin{tabular}{|c|c|c|c|c|c|c|c|c|c|}
\hline \multirow{2}{*}{\multicolumn{2}{|c|}{ Parameter }} & \multicolumn{6}{|c|}{ Cassava age (months) } & \multirow{2}{*}{ Significant level } & \multirow{2}{*}{ Suitable levels } \\
\hline & & 12 & Rating $^{\neq}$ & 24 & Rating $^{\neq}$ & 36 & Rating $^{\neq}$ & & \\
\hline $\mathrm{pH}_{\mathrm{H} 2 \mathrm{O}}$ & & $5.54 \pm 0.29$ & $\mathrm{~m}$ & $5.62 \pm 0.68$ & $\mathrm{~m}$ & $5.66 \pm 0.48$ & Medium & ns & $4.5-7.0$ \\
\hline $\mathrm{K}$ & $\mathrm{Cmol}(+) \mathrm{kg}^{-1}$ & $0.60 \pm 0.12^{\mathrm{b}}$ & $\mathrm{h}$ & $0.45 \pm 0.11^{\mathrm{a}}$ & $\mathrm{h}$ & $0.48 \pm 0.11^{\mathrm{b}}$ & $\mathrm{h}$ & $*$ & $>0.25$ \\
\hline $\mathrm{Ca}$ & $\mathrm{Cmol} \mathrm{(+)} \mathrm{kg}^{-1}$ & $0.79 \pm 0.85^{\mathrm{a}}$ & $\mathrm{h}$ & $0.96 \pm 0.81^{\mathrm{a}}$ & $\mathrm{h}$ & $1.77 \pm 2.03^{\mathrm{b}}$ & $\mathrm{h}$ & $* *$ & $1.0-5.0$ \\
\hline $\mathrm{Mg}$ & $\mathrm{Cmol} \mathrm{(+)} \mathrm{kg}^{-1}$ & $0.76 \pm 0.25$ & $\mathrm{~m}$ & $0.82 \pm 0.26$ & $\mathrm{~m}$ & $0.74 \pm 0.29$ & $\mathrm{~m}$ & ns & $0.4-1.0$ \\
\hline $\mathrm{P}^{0}$ & $\mathrm{Mg} \mathrm{kg}^{-1}$ & $37.81 \pm 15.24$ & $\mathrm{~h}$ & $32.65 \pm 12.56$ & $\mathrm{~h}$ & $36.32 \pm 17.78$ & $\mathrm{~h}$ & ns & $10-14$ \\
\hline SOC & $\%$ & $0.78 \pm 0.36^{\mathrm{a}}$ & 1 & $0.81 \pm 0.37^{\mathrm{a}}$ & 1 & $1.34 \pm 0.25^{\mathrm{b}}$ & $\mathrm{m}$ & $* * *$ & $2.0-4.0$ \\
\hline $\mathrm{N}$ & $\%$ & $0.18 \pm 0.03$ & $\mathrm{~m}$ & $0.19 \pm 0.02$ & $\mathrm{~m}$ & $0.19 \pm 0.05$ & $\mathrm{~m}$ & ns & $0.2-0.5$ \\
\hline $\mathrm{Cu}$ & $\mathrm{mg} \mathrm{kg}^{-1}$ & $0.154 \pm 0.1$ & 1 & $0.15 \pm 0.06$ & 1 & $0.16 \pm 0.05$ & 1 & ns & $0.3-0.8$ \\
\hline $\mathrm{Fe}$ & $\mathrm{mg} \mathrm{kg}^{-1}$ & $33.86 \pm 2.11$ & $\mathrm{~m}$ & $35.625 \pm 18.95$ & $\mathrm{~m}$ & $30.02 \pm 13.91$ & $\mathrm{~m}$ & ns & $4.0-6.0$ \\
\hline $\mathrm{Zn}$ & $\mathrm{mg} \mathrm{kg}^{-1}$ & $0.368 \pm 0.05$ & 1 & $0.2475 \pm 0.19$ & 1 & $0.35 \pm 0.28$ & 1 & ns & $1.0-3.0$ \\
\hline $\mathrm{Mn}$ & $\mathrm{mg} \mathrm{kg}^{-1}$ & $17.54 \pm 2.07$ & $\mathrm{~m}$ & $15.48 \pm 3.87$ & $\mathrm{~m}$ & $17.41 \pm 12.71$ & $\mathrm{~m}$ & ns & $1.2-3.5$ \\
\hline
\end{tabular}

Means followed by the same letters in a column are not significantly different from each other according to Tukey's HSD. TN = total soil nitrogen, SOC $=$ soil organic carbon, signif. codes: 0 “***” 0.001 “**” 0.01 “*” $P<0.05 ; \mathrm{vl}, l, \mathrm{~m}, h$, and vh stand for very low, low, medium, high, and very high; numbers are average ( \pm standard deviation).

EL-Sharkawy [51] found plant-available soil K concentrations to decrease from the first to the second growing season, irrespective of the fertilization treatment. This observation supports high $\mathrm{K}$ uptake by cassava. The moderate levels of exchangeable $\mathrm{Mg}$ for optimal cassava production (Table 4) indicates nutrient imbalance and could limit cassava growth and the need for a fertilizer regime. Higher $\mathrm{K}$ levels due to fertilizer application increases above ground biomass and dilutes plant $\mathrm{Ca}$ and $\mathrm{Mg}$ concentration, thus affecting yield [52].

Total nitrogen was less than $1 \%$ and rated as moderately suitable (Table 4) for optimal cassava production [53]. These findings are consistent with those of several studies which have observed nitrogen as the most limiting macronutrient in the tropical regions of sub-Saharan Africa [54]. For example, in a soil suitability assessment for cassava production in Nigeria, the total nitrogen contents of surface and subsurface soils were found to be lower than the critical limits of 0.08 and $0.05 \%$, respectively [55]. Results from this study are consistent with those reported by Imakumbili et al. [29] who found that low levels of organic matter are associated with very low levels of total nitrogen under cassava systems in Tanzania. The lower nitrogen levels in shifting cultivation systems could be because of the oxidation of organic carbon and subsequent volatization during slash and burn, which limits the organic matter available for nitrogen mineralization [46]. However, at $36 \mathrm{MAP}$, there is a moderate level of SOC, and this is due to organic matter build up after the slash and burn activity. Potassium is associated with $\mathrm{N}$ metabolism through protein synthesis, and $\mathrm{K}$ fertilizer application has been reported to increase the concentrations of $\mathrm{N}$ and $\mathrm{K}$ in all parts of cassava plants [52].

\subsection{Effects of Cropping Practices on Cassava Characteristics}

3.3.1. Cassava Leaf Area Index, Light Interception, and Tuber Yield. Results on cassava LAI tuber yield, plant density, intercepted radiations, and light extinction coefficients at 12, 24, and 36 MAPS are presented in Table 2. There was a

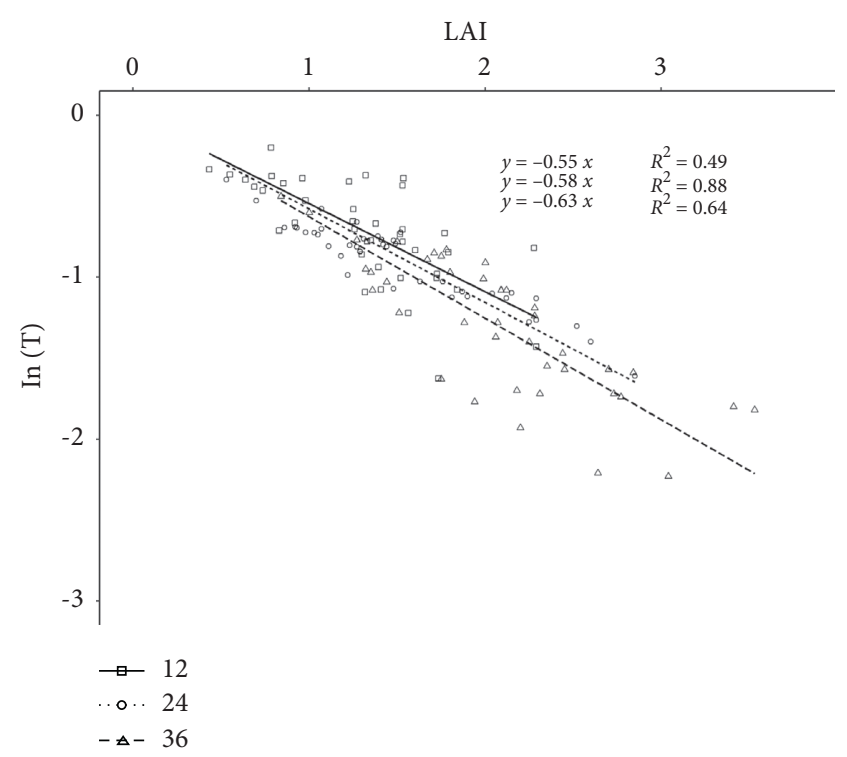

FIGURE 3: Light extinction coefficient in cassava of different maturity stages at 12,24 , and 36 MAP.

nonsignificant difference in plant density, intercepted radiations, and light extinction coefficients across the 3 cassava maturity stages $[12,24,37]$. However, there was a significant difference $(P<0.05)$ in cassava LAI at 24 MAP only. The LAI ranged from $0.87-1.75,0.97-2.07$, and $1.46-2.68$, respectively. The average light extinction coefficients $(k)$ in cassava at 12,24 , and $36 \mathrm{MAP}$ were $0.56,0.59$, and 0.64 , respectively (Figure 3 ). The cassava light extinction coefficients increased from 12 to 36 MAP and varied from $0.53-0.58,0.61-0.69$, and $0.62-0.66$ at 12,24 , and 36 MAP, respectively.

The light extinction coefficient $(k)$ is a function of leaf size and orientation, and the values obtained in this study are within the recommended range of 0.3 to 1.3 [56]. Values of $k$ less than 1 indicate clumped leaf distribution and greater light penetration, while those with values above 1 show more horizontal leaves and greater light interception $[57,58]$. The 
average light extinction coefficients $(k)$ were higher in cassava at 36 and 24 MAP maturity stages than 12 MAP (Table 2, Figure 3). This indicates more light interception for the cassava at 36 MAPS age than at 24 and 12 MAPS. This could be attributed to a higher density and better leaf positioning, possibly as a result of differences in leaf curving and leaf angles among the different years. This pattern corresponds to the work of Pellet and EL-Sharkawy [51] which obtained higher $k$ values in fertilizer treatment than in unfertilized treatments. The $k$ values obtained in this study are within the range of $0.50-0.78$ also reported by Pellet and EL-Sharkawy [51] in Cauca, Colombia, for different varieties under fertilized and unfertilized conditions.

The yields and LAI were lower at 12 MAPS than at 36 MAPS. The tuber yield was characterized by higher variability. The average fresh yields of cassava at 12, 24, and 36 MAP were 6.01, 19.68, and 23.95 t/ha (Table 2).

The LAI for cassava, regardless of the maturity age, was below the critical level of 2.5-3.5, considered ideal for tuber production [59, 60]. Howler [47] observed an LAI greater than 4 to indicate higher nitrogen fertilization, which enhances more of vegetative growth by partitioning assimilates for the growth of storage roots. Similarly, Lahai [61] observed excessively larger canopies to reduce yield due to shaded leaves which respire more carbon than partitioning it to tubers. Biratu et al. [35] found an LAI of 2.7 which is within the ideal range considered for tuber production in Zambia after a combined application of 1.4 to $\mathrm{ha}^{-1}$ manure $+150 \mathrm{~N}: 33 \mathrm{P}: 124.5 \mathrm{~K} \mathrm{~kg} \mathrm{ha}^{-1}$. The LAI was significantly positive $(r=0.39, P<0.001)$ related to soil organic carbon, an indication that available nitrogen is important in leaf area index growth. The low LAI obtained in this study could be attributed to the low soil fertility levels, similar to observations by Pellet and EL-Sharkawy [51] in Columbia for a cassava varietal response to fertilization trial. On the contrary, Cock et al. [59] observed low LAI regardless of whether the cassava was fertilized or unfertilized. The LAI was significantly correlated $(r=0.56, P<0.001)$ with intercepted radiation and tuber yield $(r=0.58, P<0.001)$. These findings are in line with many authors as this relationship is key to the amount of dry matter produced [19].

Generally, cassava tuber yields varied widely between the different fields within the same maturity age group and across different age groups (Table 2). This variability in tuber yields has been observed by several authors when cassava is grown without fertilizer and is attributed to heterogeneity in soil fertility $[10,30]$. In this study, the average farmer fresh cassava tuber yield at maturity groups of 12,24 , and $36 \mathrm{MAP}$ obtained was $6.01,19.68$, and $23.95 \mathrm{tha}^{-1}$. Yields at 24 and 36 MAP are within the range of those obtained in Uganda and Kenya of $15-40 t \mathrm{ha}^{-1}$ by Ntawuruhunga et al. [62] and Fermont et al. [33] from on-farm breeding trials. The tuber yields at 12 MAP were skewed towards the lower bounds of $617 t \mathrm{ha}^{-1}$ reported by Fermont et al. [4] in farmer fields in Kenya and Uganda without fertilizer. Several other on-farm studies showed higher yields at 12 MAPS than in this study which includes 6-10 $t \mathrm{ha}^{-1}$ [63] and $10.6 t \mathrm{ha}^{-1}$ in Kenya, $12.0 t \mathrm{ha}^{-1}$ in Uganda [64], 8.6 $\mathrm{ha}^{-1}$ [33] and 13-14t $\mathrm{ha}^{-1}$ in DR Congo [10], and 7-17t ha ${ }^{-1}$ in DR Congo [30].
Munyahali [11] obtained 20-25t ha $\mathrm{h}^{-1}$ of tuber yield under field trials, which is higher than those in this study at 12 and 24 MAPS but consistent with 36 MAPS. According to Cock et al. [59], potential fresh root yields of 75-90 $t \mathrm{ha}^{-1}$ are attainable for the late branching genotype that possesses large leaves with a long leaf life. Similarly, El-Sharkawy [65] observed that yields of between 25 and $30 t \mathrm{ha}^{-1}$ of dry matter are attainable under experimental conditions in Colombia and India. These reported cassava yields in the literature were acquired at 12 MAPS which is higher or comparable to the yields obtained at 24 or 36 MAPS in the study. Thus, there is great potential to obtain yields of even more than $20 t \mathrm{ha}^{-1}$ at 12 MAPS in the study area if fertilizer regimes can be adopted. Furthermore, this could be attributed to the unimodal rainfall pattern experienced in Zambia in which cassava undergoes a physiological rest mainly in the dry seasons and cold seasons associated with stagnant growth (Figure 1). This could imply water management in the form of irrigation could increase cassava productivity.

\subsection{Factors Affecting Tuber Yield within Each Cassava Ma-} turity Group. Table 5 presents soil, plant, and management practices which explained the differences between low and high yields based on the median within each maturity group.

The low- and high-yielding farmers ranged from 2.7-5.6 and 5.7-12 $t \mathrm{ha}^{-1}$ at 12 MAP. At 24 MAPS, the low- and high-yield categories were 9-20 and 20-34 $t$ ha $^{-1}$ respectively. The low- and high-yield categories were 7-23 and 24-35 $t \mathrm{ha}^{-1}$, respectively, at 36 MAPS. At 12 MAP, weeding frequency $(P<0.01)$ was the parameter explaining yield differences between high- and low-yielding farmers. Meanwhile, at 24 and $36 \mathrm{MAP}$, exchangeable $\mathrm{K}(P<0.03)$, LAI $(P<0.01)$, and SOC $(P<0.01)$ significantly distinguished yield differences between high- and low-yielding farms.

Weeding was a significant $(P<0.05)$ parameter explaining the yield differences between low- and highyielding farms for cassava 12 MAP (Table 5). The exchangeable $\mathrm{K}, \mathrm{SOC}$, and LAI were the significant $(P<0.05)$ parameters explaining the yield differences between lowand high-yielding farms for cassava at 24 and 36 MAP maturity stages (Table 5). This could be attributed to the higher intercepted radiation enhanced by the quick establishment of LAI due to the higher exchangeable $\mathrm{K}$ levels $[52,66,67]$. The higher uptake of exchangeable $\mathrm{K}$ has been observed to have synergist effects in cassava which brings about increased uptake of other nutrients such as exchangeable $\mathrm{Mg}$ and $\mathrm{Ca}[52,67]$ which optimizes growth and increases yields.

\subsection{Determinants of Tuber Yield at Each Cassava Maturity} Group. A stepwise regression for the datasets revealed weeding frequency $(r=0.34, P<0.000)$, LAI $(r=0.33$, $P<0.000)$, soil organic carbon (SOC) $(r=0.17, P<0.000)$, and exchangeable magnesium $(r=0.08, P<0.000)$ arranged 
TABLE 5: Comparison of yields under current soil, plant, and management practices within each cassava maturity group.

\begin{tabular}{|c|c|c|c|c|c|c|c|c|c|}
\hline \multirow{3}{*}{ Variable } & \multicolumn{3}{|c|}{12} & \multicolumn{3}{|c|}{24} & \multicolumn{3}{|c|}{36} \\
\hline & \multicolumn{9}{|c|}{ Months after planting (MAP) } \\
\hline & $5.7-12$ & $\begin{array}{r}2.7-5.6 \\
t \mathrm{ha}^{-1}\end{array}$ & $P$ value & $20-34$ & $\begin{array}{l}9-20 \\
t \mathrm{ha}^{-1}\end{array}$ & $P$ value & $24-35$ & $\begin{array}{l}9-20 \\
t \mathrm{ha}^{-1}\end{array}$ & $P$ value \\
\hline $\mathrm{K}\left(\mathrm{cmolc} \mathrm{kg}^{-1}\right)$ & 0.52 & 0.48 & ns & 0.52 & 0.38 & * & 0.52 & 0.46 & * \\
\hline SOC (\%) & 0.94 & 1.02 & ns & 1.23 & 0.92 & $*$ & 1.32 & 1.44 & $*$ \\
\hline LAI & 1.29 & 1.33 & ns & 2.13 & 1.37 & $*$ & 2.21 & 2.0 & $*$ \\
\hline WF & 1.45 & 1.10 & $*$ & 2.76 & 2.58 & ns & 2.83 & 2.48 & ns \\
\hline
\end{tabular}

$\mathrm{WF}=$ weeding frequency, $\mathrm{SOC}=$ soil organic carbon, asterisks denote significance within the age group at $P=0.05$, and ns denotes not difference within the age group.

TABLE 6: Determining factors and their correlation with cassava yield at various maturity stages.

\begin{tabular}{|c|c|c|c|c|c|c|c|c|c|c|c|c|}
\hline \multirow{3}{*}{ Variable } & \multicolumn{9}{|c|}{ Cassava age (months) } & \multirow{2}{*}{\multicolumn{3}{|c|}{ All datasets $(n=120)$}} \\
\hline & \multicolumn{3}{|c|}{$12(n=40)$} & \multicolumn{3}{|c|}{$24(n=40)$} & \multicolumn{3}{|c|}{$36(n=40)$} & & & \\
\hline & $t /$ ha & rs & $P$ value & $t \mathrm{ha}^{-1}$ & rs & $P$ value & $t \mathrm{ha}^{-1}$ & rs & $P$ value & $t \mathrm{ha}^{-1}$ & rs & $P$ value \\
\hline $\mathrm{K}$ & 0.435 & 0.19 & 0.000 & 0.268 & 0.37 & 0.023 & 0.406 & 0.28 & 0.003 & & & \\
\hline $\mathrm{Mg}$ & & & & 0.525 & 0.2 & 0.000 & 0.326 & 0.38 & 0.016 & 0.188 & 0.08 & 0.018 \\
\hline LAI & & & & 0.262 & 0.19 & 0.017 & & & & 0.313 & 0.33 & 0.000 \\
\hline SOC & & & & & & & 0.255 & 0.11 & 0.028 & 0.245 & 0.17 & 0.004 \\
\hline WF & & & & & & & & & & 0.425 & 0.34 & 0.000 \\
\hline
\end{tabular}

Variables were scaled beforehand to enable comparison, and significant differences are indicated as $P<0.05 ; \mathrm{rs}=$ correlation coefficient; WF $=$ weeding frequency, SOC = soil organic carbon.

in order of importance as the main factors explaining the variability observed in cassava yields (Table 6). For every unit increment in exchangeable $\mathrm{K}(\mathrm{cmol}(+) / \mathrm{kg}$ soil), the cassava yield increased by $435 \mathrm{~kg} \mathrm{ha}^{-1}$ at 12 MAP. At 12 MAPS, exchangeable $\mathrm{K}$ was the main factor explaining $19 \%$ of the tuber yield variability $(P<0.049)$ (Table 6). At 24 $\mathrm{MAP}$, for every unit increment in $\mathrm{K}, \mathrm{Mg}$, and LAI, cassava yield increased by 268,525 , and $262 \mathrm{~kg} \mathrm{ha}^{-1}$, respectively. The main factors explaining yield variability at $24 \mathrm{MAP}$, arranged in order of importance, were exchangeable $\mathrm{Mg}$ $(r=0.20, P<0.00)$, exchangeable $\mathrm{K}(r=0.37, P<0.05)$, and LAI $(r=0.19, P<0.05)$ (Table 6). At 36 MAPS, for every unit increment in SOC, exchangeable $\mathrm{K}$, and $\mathrm{Mg}$, cassava yield increased by 255,406 , and $326 \mathrm{~kg} \mathrm{ha}^{-1}$, respectively. Therefore, exchangeable $\mathrm{Mg}(r=0.38, P<0.00), \mathrm{K}(r=0.28$, $P<0.01)$, and SOC $(r=0.15, P<0.01)$ at 36 MAPS arranged in order of importance were the main factors explaining variability in cassava yields (Table 6). For every unit increment in Mg, LAI, SOC, and weeding frequency on all datasets, cassava yield increased by $188,313,245$, and $425 \mathrm{~kg} \mathrm{ha}^{-1}$, respectively. Weeding frequency, LAI, SOC, and exchangeable $\mathrm{Mg}$ arranged in order of importance were the main factors explaining cassava yield variability for the whole area.

The various variables accounted for 18.9, 62.8, and 64.5\% of the variation in observed tuber yields for cassava maturity stages of 12, 24, and $36 \mathrm{MAP}$, respectively. For all datasets, the variables exchangeable $\mathrm{Mg}$, LAI, SOC, and weeding frequency explained $57.4 \%$ of the variation in the observed cassava tuber yields.

Exchangeable potassium was the common determinant of tuber yield in cassava at 12, 24, and 36 MAP (Table 6). Exchangeable $\mathrm{K}$ has several functions in plant growth; among them is the quick reestablishment of the leaf area of the crop, which consequently improves yield [52, 66, 67]. This is confirmed by a significant positive correlation $(r=0.56, P<0.001)$ between $\mathrm{K}$ and LAI, which was also positively correlated $(r=0.81, P<0.001)$ with intercepted photosynthetic radiation in this study. Additionally, exchangeable $\mathrm{Mg}$, LAI, and SOC were limiting factors to tuber yield in cassava at maturity stages of 24 and $36 \mathrm{MAP}$ and across the whole area.

Exchangeable $\mathrm{Mg}$ being limiting in tuber yield could indicate the need to include it in fertilization regimes. Several authors have observed exchangeable $\mathrm{K}$ to influence the mineral nutrition of $\mathrm{Ca}$ and $\mathrm{Mg}[52,66,67]$. Kintché et al. [10] found imbalanced $\mathrm{K}$ versus exchangeable $\mathrm{Ca}$ and $\mathrm{Mg}$ to be the limiting factor in most cases in the DR Congo. This nutrient imbalance is supported by many authors who have found cassava to take up more potassium from the soil than $\mathrm{Ca}$ and $\mathrm{Mg}[3,50]$. In a cassava soil suitability assessment in Nigeria, total nitrogen, exchangeable cations, and phosphorus were found to be deficient and limited tuber formation [55]. Apart from exchangeable $\mathrm{K}$ and $\mathrm{Mg}$, Munyahali [11] further found soil reaction $(\mathrm{pH})$ to be one of the factors explaining the variability observed in cassava yields in DR Congo. This finding corresponds to the results in this study in which exchangeable $\mathrm{Mg}$ was one of the factors explaining the variability in cassava tuber yield at $24 \mathrm{MAP}$ and 36 MAP and across the whole area. In this study, SOC was lower (Table 4) and the limiting factor in cassava at 36 MAPS and the entire area. Soil organic carbon being the major source of available nitrogen could explain why nitrogen is moderately suitable for cassava production in the study area. The moderate suitability of nitrogen 
(Table 4) seems to further limit LAI and intercepted radiation with consequent low tuber yields.

Weeding frequency was the most significant $(P<0.001)$ contributing factor in explaining $34 \%$ of the observed variability in tuber yield across the area (Table 6). Furthermore, weeding frequency was the significant $(P<0.05)$ main variable explaining the differences between high- and lowyielding farmers in cassava at 12 MAP (Table 5). As in the present study, several other studies have recognized poor weed management as an important constraint to cassava production $[11,33,36,68]$. Majority of farmers in this study weeded twice during the entire cassava cycle which is recommended to increase cassava productivity when carried out at the right time [10].

Despite the slash and burn method being productive for three cassava growth cycles of up to 9 years (Table 1), this practice is not sustainable in the long run due to soil nutrient depletion and causes farmers' shift to other places [17]. Similarly, Howeler [49] found exchangeable K to decrease to $0.07 \mathrm{cmol}(+) / \mathrm{kg}$ below the critical level of $0.15 \mathrm{cmol}_{(+)} \mathrm{kg}^{-1}$ in the seventh year of continuous cassava cultivation without $\mathrm{K}$ fertilizer application at CIAT-Quilichao in Colombia. In India, Kabeerathumma et al. [69] observed a yield decrease from $22 \mathrm{t} / \mathrm{ha}$ in the first year to about $6 \mathrm{tha}$ in the tenth year without $\mathrm{K}$ fertilizer application. These results from this study are consistent with those from Den Doop [70] who reported a decrease in cassava yields after three consecutive plantings without applied $\mathrm{K}\left(15 t \mathrm{ha}^{-1}\right.$ in the first year to $4 t \mathrm{ha}^{-1}$ in the third year). The intercropping of legumes in cassava systems may help to suppress weed pressure and complement the little fertilizer applied in cassava production systems. Moreover, the use of balanced $\mathrm{K}$ fertilizers in cassava systems can impede nutrient mining while sustaining cassava production without land degradation.

\section{Conclusions}

Cassava is intercropped with maize, beans, and cowpea to suppress weeds and reduce labour, ultimately achieving food security. Shifting cultivation can only support cassava production for up to 8-9 years in which the field is abandoned due to substantial cassava yield decline every year of cultivation. Soil nutrients of $\mathrm{K}, \mathrm{Ca}$, and $\mathrm{P}$ were adequate for cassava production. The low yields in this study could be explained by the low to moderate levels of soil organic carbon (SOC) which concede to moderate suitability of $\mathrm{N}$ for optimal cassava production. Under slash and burn, there is limited SOC and, thus, lowering $\mathrm{N}$ which limits LAI expansion resulting in reduced intercepted radiation and yields. Average fresh cassava root yields ranged from 3.51-8.51, 13.52-25.84, and 16.92-30.98 $t \mathrm{ha}^{-1}$ at 12, 24, and 36 MAP, respectively. Soil organic carbon, LAI, exchangeable $\mathrm{K}$, and $\mathrm{Mg}$ explained yield differences at 24 and 36 MAP while weeding was important at $12 \mathrm{MAP}$. Despite being above the soil critical limit, exchangeable $\mathrm{K}$ was the common limiting factor affecting all cassava maturity groups. This could be due to the moderate availability of exchangeable $\mathrm{Mg}$ and low $\mathrm{N}$ which limits the efficient use of $\mathrm{K}$ in plant functions, thus causing low yields. The results suggest that legume species, fertilizer, pesticide, and fungicide integration in cassava production systems should be promoted with the immediate benefits of improved food security and increased income and, in the long run, improving soil fertility. Such technologies could ensure sustainable land use without causing further deforestation and increased cassava production, thus improving the people's livelihood.

\section{Data Availability}

All data supporting the conclusions of this study are included in this article.

\section{Conflicts of Interest}

The authors declare no conflicts of interest.

\section{Authors' Contributions}

PK carried out the experiment and wrote the manuscript. SM helped in the field interview, cassava, and soil sampling, helped to complete the plant and soil sampling in the field, and performed the laboratory measurements. $\mathrm{HS}$ and $\mathrm{BCH}$ initiated and suggested the experiments and are responsible for this study and reviewed and finalized the manuscript. MC helped in government protocol and linkage between the farmers in the study area. KM helped in study location and read and approved the final manuscript. PK, SM, and DPM carried out the statistical analysis and reviewed the manuscript. AS created the figures and reviewed the manuscript. EI acquired the funding for the research and read the manuscript. All authors read and approved the final manuscript.

\section{Acknowledgments}

Gratitude goes to the Federal Government of Germany, Ministry of Agriculture and Food, and the University of Zambia for financial support. Lastly, the authors are grateful to the Zambian Government through the Ministry of Agriculture in Nchelenge District and the people of Mantapala for assistance during the data collection. This research was supported by the Federal Office for Agriculture and Food (BLE), International Cooperation and Global Food Security 323, Germany (grant no. $1^{\text {st }}$ of January, 2017) and the University of Zambia.

\section{References}

[1] B. Bennett, "Guest editorial: smallholder cassava production and the cassava processing sector in Africa," Food Chain, vol. 5, no. 1-2, pp. 1-3, 2015.

[2] S. Latif and J. Müller, "Potential of cassava leaves in human nutrition: a review," Trends in Food Science \& Technology, vol. 44, no. 2, pp. 147-158, 2015.

[3] R. H. Howeler, "Long-term effect of cassava cultivation on soil productivity," Field Crops Research, vol. 26, no. 1, pp. 1-18, 1991.

[4] A. M. Fermont, P. A. Tittonell, Y. Baguma, P. Ntawuruhunga, and K. E. Giller, "Towards understanding factors that govern fertilizer response in cassava: lessons from East Africa," 
Nutrient Cycling in Agroecosystems, vol. 86, no. 1, pp. 133-151, 2010.

[5] E. Styger, H. M. Rakotondramasy, M. J. Pfeffer, E. C. M. Fernandes, and D. M. Bates, "Influence of slash-andburn farming practices on fallow succession and land degradation in the rainforest region of Madagascar," Agriculture, Ecosystems \& Environment, vol. 119, no. 3-4, pp. 257-269, 2007.

[6] R. C. Wickramasuriya, A. K. Bregt, H. Van Delden, and A. Hagen-Zanker, "The dynamics of shifting cultivation captured in an extended constrained cellular automata land use model," Ecological Modelling, vol. 220, no. 18, pp. 2302-2309, 2009.

[7] P. Roudier, B. Sultan, P. Quirion, and A. Berg, "The impact of future climate change on West African crop yields: what does the recent literature say?" Global Environmental Change, vol. 21, no. 3, pp. 1073-1083, 2011.

[8] P. Ntawuruhunga, M. Chiona, N. Manda, S. Korie, and J. Njobvu, “Assessment of performance and farmers' preference varieties through participatory variety selection and calls for doubling breeding effort in Zambia," in Proceedings of the Paper Presented at the 12th Triennial Symposium of International Society for Tropical Root Crops- Africa Branch (ISTRC-AB), Accra, Ghana, November 2013.

[9] K. S. Ezui, A. C. Franke, A. Mando et al., "Fertiliser requirements for balanced nutrition of cassava across eight locations in West Africa," Field Crops Research, vol. 185, pp. 69-78, 2016.

[10] K. Kintché, S. Hauser, N. M. Mahungu et al., "Cassava yield loss in farmer fields was mainly caused by low soil fertility and suboptimal management practices in two provinces of the democratic republic of Congo," European Journal of Agronomy, vol. 89, pp. 107-123, 2017.

[11] W. Z. Munyahali, Nutrient Requirements of Cassava under Different Management Systems in South Kivu, Dr Congo, PhD thesis, Katholieke Universiteit Leuven, Faculty of Bioscience Engineering, Leuven, Belgium, 2017.

[12] R. H. Howeler and L. F. Cadavid, "Accumulation and distribution of dry matter and nutrients during a 12-month growth cycle of cassava," Field Crops Research, vol. 7, pp. 123-139, 1983.

[13] I. H. Salcedo, H. Tiessen, and E. V. S. B. Sampaio, "Sampaio nutrient availability in soil samples from shifting cultivation sites in the semi-arid caatinga of NE Brazil," Agriculture, Ecosystems \& Environment, vol. 65, pp. 177-186, 1997.

[14] T. B. Bruun, O. Mertz, and B. Elberling, "Linking yields of upland rice in shifting cultivation to fallow length and soil properties," Agriculture, Ecosystems \& Environment, vol. 113, pp. 139-149, 2006.

[15] R. H. Howeler, "Diagnosis of nutritional disorders and soil fertility maintenance of cassava," in In Tropical Tuber Crops: Problems, Prospects and Future Strategies, G. T. Kurup, Ed., pp. 181-193, Oxford and IBH Publishing Co. Pvt. Ltd., New Delhi, India, 1996.

[16] O. Mertz, S. J. Leisz, A. Heinimann et al., "Who counts demography of swidden cultivators in southeast asia," Human Ecology, vol. 37, pp. 281-289, 2009.

[17] P. Chase and O. P. Singh, "Soil nutrients and fertility in three traditional land use systems of khonoma," Nagaland, India, Resources and Environment, vol. 4, pp. 181-189, 2014.

[18] V. O. Sadras, F. J. Villalobos, and E. Fereres, "Radiation interception, radiation use efficiency and crop productivity," in Principles of Agronomy for Sustainable Agriculture, pp. 169188, Springer, Berlin, Germany, 2016.
[19] K. Tesfaye, S. Walker, and M. Tsubo, "Radiation interception and radiation use efficiency of three grain legumes under water deficit conditions in a semi-arid environment," European Journal of Agronomy, vol. 25, pp. 60-70, 2006.

[20] A. Sennhenn, D. M. G. Njarui, B. L. Maass, and A. M. Whitbread, "Understanding growth and development of three short-season grain legumes for improved adaptation in semi-arid Eastern Kenya," Crop \& Pasture Science, vol. 68, pp. 442-456, 2017.

[21] J. E. Begg, "Morphological adaptations of leaves to water stress," in Adaptations of Plants to Water and High Temperature Stress, N. C. Turner and P. J. Kramer, Eds., pp. 33-42, Wiley, New York, NY, USA, 1980.

[22] J. E. Mansfield, J. G. Bennet, R. B. King, D. M. Lang, and R. M. Lawton, Land Resources of the Northern and Luapula Provinces, Zambia, a Reconnaissance Assessment, 4 Volumes, Land Resources Division, Ministry of Overseas Development, London, UK, 1975, https://library.wur.nl/isric/fulltext/isricu_ i7323_002.pdf.

[23] D. W. Nelson and L. E. Sommers, "Total carbon, organic carbon and organic matter," in Methods of Soil Analysis, Part 2: Chemical and Microbiological Properties, A. L. Page, Ed., pp. 539-579, American Society of Agronomy, Madison, WI, USA, 1982.

[24] J. M. Bremner, "Inorganic forms of nitrogen," in Methods of Soil Analyst; Part 2 Chemical and Microbiological Properties, C. A. Black, Ed., vol. 9pp. 1179-1237, American Society of Anesthesiologists, Schaumburg, IL, USA, 1969, http://garfield. library.upenn.edu/classics1980/A1980JC06900001.pdf.

[25] E. Van Ranst, M. Verloo, A. Demeyer, and J. M. Pauwels, Manual for the Soil Chemistry and Fertility Laboratory, Ghent University, Ghent, Belgium, 1999.

[26] H. J. Veltkamp, "Physiological causes of yield variation in cassava," Agricultural University Wageningen, vol. 85, no. 6, pp. 1-103, 1985.

[27] A. A. C. Alves, Cassava Botany and Physiology, Cassava: Biology, Production and Utilization, CABI Publishing, Wallingford, UK, pp. 67-89, 2002.

[28] R. J. Hillocks, "Cassava in Africa," in Cassava: Biology, Production and Utilization, R. J. Hillocks, J. M. Thresh, and A. C. Bellotti, Eds., pp. 41-54, CABI Publishing, Wallingford, UK, 2002, https://www.oecd-ilibrary.org/docserver/ 9789264253421-6-en.pdf.

[29] M. L. E. Imakumbili, E. Semu, J. M. R. Semoka, A. Abass, and G. Mkamilo, "Soil nutrient adequacy for optimal cassava growth, implications on cyanogenic glucoside production: a case of konzo-affected Mtwara region, Tanzania," PLoS One, vol. 14, pp. 1-17, 2019.

[30] W. Z. Munyahali, Nutrient Requirements of Cassava under Different Management Systems in South Kivu, Dr Congo, PhD Thesis, Faculty of Bioscience Engineering, Katholieke Universiteit Leuven, 2018.

[31] CIALCA, CIALCA Baseline survey report, "Consortium for improving agriculture-based livelihoods in central Africa," Led by IITA, Kampala, TSFB-CIAT, Nairobi, Bioversity Int., Kampala, Kampala, Uganda, 2010, http://www.cialca.org/.

[32] A. E. Agwu and C. L. Anyaeche, "Adoption of improved cassava varieties in six rural communities in Anambra State, Nigeria," Journal of Biotechnology, vol. 6, pp. 089-098, 2007.

[33] A. M. Fermont, P. J. A. Van Asten, P. Tittonell, M. T. Van Wijk, and K. E. Giller, "Closing the cassava yield gap: an analysis from smallholder farms in East Africa," Field Crops Research, vol. 112, pp. 24-36, 2009. 
[34] A. M. Fermont, P. J. A. Van Asten, and K. E. Giller, "Increasing land pressure in East Africa: the changing role of cassava and consequences for sustainability of farming systems," Agriculture, Ecosystems \& Environment, vol. 128, pp. 239-250, 2008.

[35] K. G. Biratu, E. Elias, P. Ntawuruhunga, and W. G. Sileshi, "Cassava response to the integrated use of manure and NPK fertilizer in Zambia," Heliyon, vol. 4, no. 8, 2018.

[36] D. Leihner, "Agronomy and cropping practices," in Cassava: Biology, Production and Utilization, R. J. Hillocks, J. M. Thresh, and A. Bellotti, Eds., CABI, Wallingford, UK, pp. 91-114, 2002.

[37] G. K. Biratu, E. Elias, P. Ntawuruhunga, and N. Nhamo, "Effect of chicken manure application on cassava biomass and root yields in two agro-ecologies of Zambia," Agriculture, vol. 8, no. 4, p. 45, 2018.

[38] S. Adjei-Nsiah, T. W. Kuyper, C. Leeuwis, M. K. Abekoe, and K. E. Giller, "Evaluating sustainable and profitable cropping sequences with cassava and four legume crops: effects on soil fertility and maize yields in the forest/savannah transitional agro- ecological zone of Ghana," Field Crops Research, vol. 103, pp. 87-97, 2007.

[39] J. O. Fening, T. A. Gyapong, F. Ababio, and E. Gaisie, "Effect of site characteristics on the productivity and economic returns from cassava legume intercropping in Ghana," African Journal of Environmental Science and Technology, vol. 3, no. 10, pp. 326-331, 2009.

[40] D. J. Greenland, P. J. Gregory, and P. H. Nye, "Land resources: on the edge of the Malthusian precipice: introduction and conclusions," Philosophical Transactions of the Royal Society of London, Series A B, vol. 352, pp. 861-867, 1997.

[41] IITA, Cassava in Tropical Africa, A Reference Manual, Balding and Marsell, pp. 1-8, IITA, Ibadan, Nigeria, 1990, https:// www.iita.org/wp-content.

[42] NACWC, National Advisory Committee on Weed Control. Weed Control Recommendations for Nigeria, p. 111, NACWC, Benin City, Nigeria, 1994.

[43] A. A. Enete, F. I. Nweke, and E. Tollens, "Hired labor use decisions in cassava-producing households of Sub-Saharan Africa," Agricultural Economics, vol. 33, pp. 269-275, 2005.

[44] R. G. Lockard, M. A. Saqui, and D. D. Wounuah, "Effects of time and frequency of leaf harvest on growth and yield of cassava (Manihot esculenta Crantz) in Liberia," Field Crops Research, vol. 12, pp. 175-180, 1985.

[45] A. B. Junqueira, T. J. Stomph, C. R. Clement, and P. C. Struik, "Variation in soil fertility influences cycle dynamics and crop diversity in shifting cultivation systems," Agriculture, Ecosystems \& Environment, vol. 215, pp. 122-132, 2016.

[46] C. P. Giardina, R. L. SanfordJr., I. C. Døckersmith, and V. J. Jaramillo, "The effects of slash burning on ecosystem nutrients during the land preparation phase of shifting cultivation," Plant and Soil, vol. 220, pp. 247-260, 2000.

[47] R. H. Howeler, E. Sieverding, and S. Saif, "Practical aspects of mycorrhizal technology in some tropical crops and pastures," Plant and Soil, vol. 100, pp. 249-283, 1987.

[48] R. J. Carsky and M. A. Toukourou, "Identification of nutrients limiting cassava yield maintenance on a sedimentary soil in southern Benin, West Africa," Nutrient Cycling in AgroEcosystems, vol. 71, pp. 151-162, 2005.

[49] R. H. Howler, "Cassava mineral nutrition and fertilization," in Cassava: Biology, Production, and Utilization, R. J. Hillrocks, J. M. Thresh, and A. C. Belloti, Eds., CABI, Cali, Columbia, 2002, http://ciat-library.ciat.cgiar.org/Articulos_ciat/cabi_ 10ch7.pdf2002.
[50] S. Putthacharoen, R. H. Howeler, S. Jantawat, and V. Vichukit, "Nutrient uptake and soil erosion losses in cassava and six other crops in a Psamment in eastern Thailand," Field Crops Research Journal, vol. 57, pp. 113-126, 1998.

[51] D. M. Pellet and M. A. EL-Sharkawy, "Cassava varietal response to fertilization: growth dynamics and implications for cropping sustainability," Experimental Agriculture, vol. 1, no. 33, pp. 353-365, 1997.

[52] M. L. S. Silva and A. R. Trevizam, "Ionic interactions and their effects on plant nutrition," IPNI, vol. 149, Agronomic information, Piracicaba, Brazil, 2015, in Portuguese.

[53] CIAT, The Cassava Handbook, R. H. Howeler, Ed., Thai Watana Panich Press Co, Ltd., Bangkok, Thailand, 2011.

[54] P. A. Sanchez, Properties and Management of Soils in the Tropics, John Wiley \& Sons, New York, NY, USA, 1976.

[55] M. A. Abua, "Suitability assessment of soil for cassava production in the coastal and hinterland areas of Southern Cross River State-Nigeria," Journal of Soil Science and Environmental Management, vol. 6, no. 5, pp. 108-115, 2015.

[56] T. Saeki, "Interrelationships between leaf amount, light distribution and total photosynthesis in a plant community," Botany MagazineTokyo, vol. 73, pp. 55-63, 1960.

[57] G. Szeicz, "Solar radiation in crop canopies," Journal of Applied Ecology, vol. 11, pp. 1117-1156, 1974.

[58] H. G. Jones, Plants and Microclimate: A Quantitative Approach to Environmental Plant Physiology, Cambridge University Press, Cambridge, UK, 1992, https://www.cambridge. org/de, 2nd edition.

[59] J. H. Cock, D. Franklin, G. Sandoval, and P. Juri, "The ideal cassava plant for maximum yield," Crop Science, vol. 19, pp. 271-279, 1979.

[60] V. Lebot, Tropicalroots Andtuber Crops: Cassava, Sweetpotato, Yams Andaroids, CABI, Wallingford, UK, 2009.

[61] T. Lahai, "Influence of canopy structure on yield of cassava cultivars at various toposequences of an inland valley agro ecosystem," Journal of Agricultural Biotechnology and Sustainable Development, vol. 5, pp. 36-47, 2013.

[62] P. Ntawuruhunga, G. Ssemakula, H. Ojulong et al., "Evaluation of advanced cassava genotypes in Uganda," African Crop Science Journal, vol. 14, pp. 17-25, 2006.

[63] FAOSTAT, Food and Agriculture Organization of the United Nations, FAOSTAT, Lazio, Italy, 2018, http://www.faostat.fao.org/.

[64] FAO, http://www.faostat.fao.org, 2008.

[65] M. A. El-Sharkawy, "Cassava biology and physiology," Plant Molecular Biology, vol. 56, pp. 481-501, 2004.

[66] S. Umeh, C. Onyeonagu, and B. Umeh, "Potassium nutrition and translocation in cassava (manihot esculenta Crantz) intercropped with soybean," American Journal of Experimental Agriculture, vol. 5, no. 4, pp. 281-286, 2015.

[67] A. M. Fernandes, B. Gazola, J. G. Da Silva Nunes, E. L. Garcia, and M. Leonel, "Yield and nutritional requirements of cassava in response to potassium fertilizer in the second cycle," Journal of Plant Nutrition, vol. 40, no. 20, pp. 2785-2796, 2017.

[68] A. A. Melifonwu, "Weeds and their control in cassava," African Crop Science Journal, vol. 2, pp. 519-530, 1994.

[69] S. Kabeerathumma, B. Mohankumar, C. R. Mohankumar, G. M. Nair, M. Prabhakar, and N. G. Pillai, "Long range effect of continuous cropping and manuring on cassava production and fertility status," in Proceedings of the 8th Symposium International Society of Tropical Root Crops, pp. 259-269, Bangkok, Thailand, October 1988.

[70] J. E. A. Den Doop, "Green manuring, artificial manure and other factors in sisal and cassava production," Bergcultures, vol. 11, no. 9, pp. 264-278, 1937. 